www.jmscr.igmpublication.org

Impact Factor (SJIF): 6.379

Index Copernicus Value: 71.58

ISSN (e)-2347-176x ISSN (p) 2455-0450

crossrefDOI: https://dx.doi.org/10.18535/jmscr/v6i6.81

Journal Of Medical Science And Clinical Research

\title{
A Cross Sectional Study on Knowledge, Awareness and Practices Regarding RTIs/STDs among Married Tribal Women (Aged 25 - 45 years) in Northern India
}

\author{
Ruqia Quansar ${ }^{1}$, Hina Bashir ${ }^{2}$, Mohsina Mukhtar ${ }^{3}$, S.M. Salim Khan ${ }^{4}$, Mahk Nelofar ${ }^{5}$ \\ ${ }_{1,2,3,5}$ Postgraduate scholar, in Department of Community Medicine, Government Medical College Srinagar, \\ Jammu and Kashmir \\ ${ }^{4}$ Professor and Head, Department of Community Medicine, Government Medical College, Srinagar, Jammu \\ and Kashmir \\ Corresponding Author
}

Ruqia Quansar

Email: ruqiaquansar@gmail.com, Phone no.9796742575

Address: Housing Colony near Masjid Ibrahim House no 53, Sector 1/A, Bemina, Srinagar,

Jammu and Kashmir, India

\begin{abstract}
Background: Reproductive Tract Infections (RTIs) including Sexually Transmitted infections (STIs) are silent epidemics and are recognized as public health problem and are the cause of healthy life lost among women of reproductive age. The problem of RTI/STD morbidity in women is largely due to ignorance, low level of awareness regarding sexual and reproductive health and other social factors like low female literacy, cultural factors and taboos - all withholding the women from seeking health care for RTI/STDs. Tribal communities are always been distinct with their unique culture, traditions, believes and practices. In the context of the rapid spread of RTI/STD infection in India, it is very essential to understand the knowledge regarding various aspects of RTI/STD among the tribal women of India.

Methodology: A community based cross sectional study was conducted in Tribal area of District Srinagar from March 2016 to December 2016. Married women (age 25- 45 years) were selected randomly from the area. A total of 204 married women were interviewed using pre-structured questionnaire.

Results: In our study, the majority of women were in the age group of 31-35 years (40\%), illiterate (84.8\%), belonged to nuclear families (59.32\%) and were multipara $(>3=60.3 \%) .48 .5 \%$ women had heard about RTI/STDs. $58.5 \%$ women opted for treatment and only $36.3 \%$ women had their husbands also treated.

Conclusion: Overall the knowledge, awareness and practices were poor among the tribal women. There is a need for imparting awareness regarding the transmission and prevention of RTI/STDs.

Keywords: Tribal women, Reproductive tract infection, Knowledge, Awareness, Practice.
\end{abstract}




\section{Introduction}

Reproductive mortality includes problems related to reproductive organs and functions. They are caused by biological agents and are also related to women poverty and lack of awareness and hygiene. RTI/STDs are silent epidemic and a global health problem especially in developing countries. ${ }^{(1)}$ Globally357 million new cases of sexually transmitted infections occur in 15-49 years population every year ${ }^{(2)(3)}$. In India $11 \%$ of women and 5\% of men in the age group of 15-49 years had complained of symptoms suggestive of STI/RTIs in the 12 months preceding the survey ${ }^{(4)}$. It is evident from different studies that there is rise in the sero prevalence of syphilis in India and other countries in recent times either due to actual increase in the disease or as a result of increased awareness and surveillance system. ${ }^{(5)}$

RTI/STDs are communicable disease transmitted by sexual contact and have bacterial, viral, protozoal and fungal causative agents. They cause wide range of morbidity and mortality. ${ }^{(6)}$ The problem due to reproductive tract infections in form of different morbidity and mortality in women is ignored because the women are reluctant to visit a health care provider or they find it difficult to discuss their gynaecological problems with others. ${ }^{(7)}$ Poor understanding of symptoms, cultural barriers, lack of privacy, the cost of treatment, social stigma and fear of examination are the factors for delay in seeking treatment. $^{(8)}$

Tribal communities have distinct and unique culture and traditions and beliefs and practices. The developmental activities reach them by lately and which may be a reason for low awareness related to health issues. It is thus essential to know about the knowledge and practices regarding RTI/STDs among tribal people. ${ }^{(6)}$

\section{Aim and Objectives}

To assess knowledge, awareness and practices regarding RTI/STIs among married tribal women (aged 25 - 45 years) in District Srinagar.

\section{Methodology}

It was a community based cross sectional study conducted in tribal area of District Srinagar from March 2016 till December 2016. There were total 299 married women in the age group of $25-45$ years in the area out of which 204 married women aged $25-45$ years consented to participate in the study and thus were included for the same. A house to house visit was done till the whole area was covered. Informed verbal consent was obtained from eligible women. Participants were explained the objectives of the study and were interviewed using a structured questionnaire. Information was obtained about demographic and socio-economic characteristics and reproductive history. The level of knowledge about RTI/STI was assessed by asking the participants, "What are the various symptoms in a woman who has infection of the reproductive tract/sexual organs?". Questions about transmissibility and curability were asked to further assess the knowledge about STI/RTI. The participants were asked, "What do you believe causes RTI/STI?". Treatment seeking behaviour in context of RTI/STI was enquired about. Those who reported any past experience of RTI/STI were asked about treatment completion of self and husband. The collected data was entered in Microsoft Excel. Data was described in terms of percentages.

\section{Results}

A total of 204 women were interviewed using structured questionnaire. Majority of the women belonged to age group of $31-35$ (40.20\%), were illiterate $(84.8 \%)$, belonged to nuclear family $(59.32 \%)$, having a parity of $=>3(60.3 \%)$ and belonged to upper middle class $(70.6 \%)$. [Table 1] 
Table 1: Socio - demographic characteristics of participants

\begin{tabular}{|c|c|c|}
\hline Characteristic & Number $(n=204)$ & Percentage (\%) \\
\hline \multicolumn{3}{|l|}{ Age (years) } \\
\hline $25-30$ & 68 & 33.33 \\
\hline $31-35$ & 82 & 40.20 \\
\hline $36-40$ & 49 & 24.02 \\
\hline $41-45$ & 5 & 2.45 \\
\hline \multicolumn{3}{|l|}{ Education level } \\
\hline Illiterate & 173 & 84.8 \\
\hline Primary & 10 & 4.9 \\
\hline Middle & 13 & 6.4 \\
\hline High school & 5 & 2.5 \\
\hline Higher secondary & 2 & 0.9 \\
\hline Graduate & 1 & 0.5 \\
\hline Post graduate and above & 0 & 0 \\
\hline \multicolumn{3}{|l|}{ Family type } \\
\hline Nuclear & 121 & 59.32 \\
\hline Joint & 83 & 40.68 \\
\hline \multicolumn{3}{|l|}{ Parity } \\
\hline$<3$ & 81 & 39.70 \\
\hline$=>3$ & 123 & 60.30 \\
\hline \multicolumn{3}{|l|}{ Working } \\
\hline Yes & 2 & 0.98 \\
\hline No & 202 & 99.02 \\
\hline \multicolumn{3}{|l|}{ Socio economic status" } \\
\hline Upper class & 0 & 0 \\
\hline Upper middle class & 12 & 5.9 \\
\hline Lower middle class & 144 & 70.6 \\
\hline Lower class & 48 & 23.5 \\
\hline
\end{tabular}

* using Modified Kuppuswamy socio economic scale 2016.

Ninety nine $(48.5 \%)$ participants had heard about RTI/ STD. The knowledge regarding RTI/STD was assessed among the women who had heard about RTI/STD. They were asked regarding symptoms, causes, treatability and transmissibility to and from the husband. [Table 2]

Table 2: Knowledge regarding STI/RTI among those who had heard about RTIs/STIs

\begin{tabular}{|l|l|l|}
\hline \multicolumn{2}{|l|}{ Number (n=99) } & Percentage (\%) \\
\hline \multicolumn{1}{|l|}{ Knowledge about symptoms } & 11 & 11.11 \\
\hline Curdy white discharge & 13 & 13.13 \\
\hline Itching & 04 & 4.04 \\
\hline Swelling of genitals & 12 & 12.12 \\
\hline Abdominal pain & 08 & 8.08 \\
\hline Lower back ache & 21 & 21.21 \\
\hline Foul smelling discharge & 30 & 30.30 \\
\hline Don't know & 19 & 19.19 \\
\hline Knowledge about causes & 22 & 22.22 \\
\hline Bad blood in the body & 25 & 25.25 \\
\hline Warm food & 10 & 10.10 \\
\hline Curse of God & 23 & 23.23 \\
\hline Normal process & 73 & 73.73 \\
\hline Don't know & 27 & 27.27 \\
\hline Knowledge about treatability & \\
\hline Yes & 33.3 \\
\hline No & 33 & 66.7 \\
\hline Knowledge about transmissibility to/from husband \\
\hline Yes & 66 & 19.2 \\
\hline No & 80.8 \\
\hline \multicolumn{2}{|l|}{ Treatment of husband required } & 19 \\
\hline Yes & 80 & \\
\hline No &
\end{tabular}


The women who had knowledge about RTI/STD were assessed regarding practices. They were asked questions assessing the practice. Out of 99 women, 41 (41.4\%) had suffered an episode of RTI/STD in last one year and out of 41,24 $(58.5 \%)$ women had received treatment. [Table 3]

Table 3: Practice regarding RTI/STD among women who had knowledge

\begin{tabular}{|c|c|c|}
\hline & Number (n) & Percentage $(\%)$ \\
\hline \multicolumn{3}{|c|}{ Treatment received at $(n=41)$} \\
\hline Doctor & 11 & 26.8 \\
\hline ANM & 13 & 31.7 \\
\hline Not at all & 17 & 41.5 \\
\hline \multicolumn{3}{|c|}{ Treatment completed $(n=24)$} \\
\hline Yes & 16 & 66.7 \\
\hline No & 08 & 33.3 \\
\hline \multicolumn{3}{|c|}{ Treatment of husband advised $(n=24)$} \\
\hline Yes & 11 & 45.8 \\
\hline No & 13 & 54.2 \\
\hline \multicolumn{3}{|c|}{ Treatment of husband completed (n=11) } \\
\hline Yes & 4 & 36.4 \\
\hline No & 7 & 63.6 \\
\hline
\end{tabular}

\section{Discussion}

Reproductive tract infections are of major health concern among the women of reproductive age group. These infections are ironically seldom reported due to associated social taboos with them and the fact that most of the RTIs are asymptomatic. $^{(9)}$

Majority of the study participants belonged to the age group of $31-35$ years $(40.02 \%)$ and $84.8 \%$ of the study participants were illiterate.

In this study, $48.5 \%$ (99) of the study participants had heard of RTI/STI findings similar to a study conducted by D.Ramana $(47 \%)^{(6)}$. The knowledge regarding symptoms, causes, treatability, transmissibility and whether treatment of husband is required or not was assessed among the study participants who have heard about RTI/ STD. While assessing the knowledge regarding symptoms, the most common symptom reported was foul smelling discharge (21.2\%) findings similar to the study conducted by VikasRao, Deepali et al ${ }^{(10)}$. Other symptoms reported were itching in the genital region $(13.3 \%)$, curdy white discharge (11.1\%) and abdominal pain (12.12\%). $30.30 \%$ women didn't have any knowledge regarding symptoms of RTI/STD. While assessing the knowledge regarding causes, the most common cause reported was curse of God $(25.25 \%)$ followed by warm food $(22.22 \%)$. This finding was consistent with a study conducted by Ratnaprabha et $\mathrm{al}^{(8)}$. Bad blood was reported as a cause by $19.19 \%$ of the study participants. About $10.10 \%$ of the study participants reported RTI/STD as a normal process and $23.23 \%$ didn't have any knowledge regarding causes of RTI/STD. $73.73 \%$ of the study participants had knowledge that RTI/STD is treatable. The similar findings were found in a study conducted by Rejoice Puthuchira ${ }^{(11)}$. The knowledge regarding the fact that RTI/STD is transmissible to husband or vice versa was present in $33.33 \%$ study participants. $19.2 \%$ of the study participants knew that the treatment of the husband was also required. The findings were consistent with the study by Meenakshi Bhilwar et al. ${ }^{(9)}$

Out of 99 study participants who had knowledge were asked regarding treatment seeking behaviour. 41 (41.41\%) study participants have suffered from atleast one episode of RTI/STD during last 6 months from date of interview. $26.8 \%$ of the study participants had consulteda doctor and $31.7 \%$ of the study participants had consulted ANM and $41.5 \%$ had no treatment at all. The study participants considered RTI/STD as curse of God, and some others considered it a normal process. These were the most common reasons for not seeking any treatment among the study participants. $66.7 \%$ of the study participants 
completed the prescribed treatment course and $33.3 \%$ didn't comply to the treatment prescribed to them. The findings in our study were higher as compared to a study conducted by Ratnaprabhakar et $\mathrm{al}^{(8)} .45 .8 \%$ of the study participants were also advised treatment for the husband as well by the treating physician and $36.4 \%$ of the study participant's husbands had completed treatment. The study findings were consistent with the study conducted by A J Singh ${ }^{(12)}$ and another study conducted by Samantha et $\mathrm{al}^{(13)}$.

\section{Conclusion}

The study revealed a high load of reproductive tract infections in the area. Intense measures are required to make people aware of the symptoms, mode of spread and importance of prompt treatment seeking. Special care is needed in areas which are neglected due to geographical barriers and unfavourable climate. Most of the RTIs are preventable. Preventing new cases requires educating people about the common symptoms, common methods of transmission, complications and preventive measures. There is also a need to alleviate the stigma associated with RTIs and favourably modify the treatment-seeking behaviour of the patients ${ }^{(14)}$.

\section{References}

1. Rani V, Dixit AM, Singh NP, Kariwal P. KAP Study on Reproductive Tract Infections ( RTIs ) Among Married women ( 15-44 years ) in rural area of Etawah, Uttar Pradesh. Indian J Community Med. 2016;28(1).

2. WHO. WHO, Global Health Sector Strategy on Sexually Transmitted Infections 2016 - 2021, Towards Ending STIs. 2016;13-4.

3. Department of Health and Family Welfare, NACO, Annual Report. :335-8.

4. Sciences I institute for population. National Family and Health Survey 3.

5. Dharmambal C., Somasundaram A. BJ. Knowledge regarding STI RTI services among Interns in Government Vellore Medical College March to June 2017. J Med Sci Clin Res. 2017;5(11):30983-8.

6. Ramana, D SV. A Study Of Knowledge Awareness And Perception Among RTI / STD's On Tribal Women. J Bus Manag Soc Sci Res. 2015;4(3):290-4.

7. Devi BS, Swarnalatha N. Prevalence of RTI / STI amongreproductive age women ( 15-49 years ) in urban slums of Tripura Town, Andhra Pradesh. Heal Popul Perspect issues. 2007;30(1):56-70.

8. Gk R, Thimmaiah S, Johnson AR, Ramesh N. Prevalence and awareness of reproductive tract infections among women in select underprivileged areas of Bangalore city. Int J Med Sci Public Heal. 2015;4(12):1691-6.

9. Bhilwar M, Malik A, Upadhyay R. Knowledge, care-seeking and prevalence of reproductive tract infections in tribal women of Himachal Pradesh, India. Indian J Matern child Heal. 2015;17(2).

10. Rao V, Savargaonkar D, Anvikar A, Bhondeley MK, Tiwary BK, Ukey M, et al. Reproductive Tract Infections in Tribal Women of Central India. Proceeding Natl Symp Tribal Heal. 440.

11. Ravi RP, Kulasekaran RA. A CrossSectional Study of Knowledge , Perceptions and Misconceptions about RTIs , STIs and HIV / AIDS among Young Married Rural Women in Tamilnadu State, India. World Appl Sci J. 2014;31(1):84-90.

12. Singh AJ. Vaginal discharge: Its causes and associated symptoms as perceived by rural North Indian women. Indian $\mathbf{J}$ Community Med. 2007;32:22-6.

13. Samanta A, Ghosh S MS. Prevalence and health seeking behaviour of RTI/STI's symptomatic:A cross sectional study of a rural community in the Hooghly district of West Bengal. Indian $J$ Public Heal. 2011;55(1):38-41. 
14. Sa R, Rath RS, Vivek G, Anant G, Farhad A, Vijay S. KAP Study on Sexually Transmitted Infections / Reproductive Tract Infections ( STIs / RTIs ) among married women in rural Haryana. Indian Dermatol Online J. 2015;6(1). 